\title{
PENGARUH BUDAYA KERJA TERHADAP KINERJA GURU BERSERTIFIKASI DI MADRASAH ALIYAH
}

\section{THE INFLUENCE OF WORK CULTURE TOWARD TEACHER CERTIFIED PERFORMANCE IN TEACHING AND LEARNING IN MADRASAH ALIYAH}

\author{
B Salam', M Ma'ufur ${ }^{1}$, dan S Laeli'ia \\ 1 Program Studi Manajemen Pendidikan Islam, Fakultas Keguruan dan Ilmu Pendidikan, \\ Universitas Djuanda Bogor, Jl. Tol Ciawi No. 1 Kotak Pos 35 Ciawi Bogor 16720 \\ a Korespondensi: Sobrul Laeli, Email: obbunk@gmail.com \\ (Diterima: 15-01-2017; Ditelaah: 15-01-2017; Disetujui: 01-04-2017)
}

\begin{abstract}
Teacher is the most important element in the system of education and teacher performance is the achievement of a teacher that determines the quality of the education. In producing the performance will not be separated from the culture that is applied in an educational institution. Hence, the work culture will affect the performance of teacher. This study aims to find out is there any influence between the work culture on the performance of certified teachers in the learning process. This study uses a quantitative approach to the functional correlation type. The sample in this study used a sample of saturated or census. This research was conducted in MA Daarul 'Uluum Lido Cigombong Bogor with seventeen respondents are certified teachers. The data collection techniques of research were questionnaires, interviews, observation and documentation. The validity of the data using expert validity and test validity. Data reliability using Cronbach's Alpha technique. Test requirements analysis in this study is a test for normality and linearity test. To test the hypothesis using simple linear regression. The final results of this study demonstrate the significance of the regression equation with the results tcount 4.631 and ttable with the standard error of $5 \% \mathrm{dk}=17-2=16$ was 1,746 at $5 \%$ level. Thus $t_{\text {hitung }}>t_{\text {table }}(4,631>1,746)$ so that $\mathrm{H}_{0}$ is rejected, meaning that a significant difference between the work culture on the performance of certified teachers in the learning process. The coefficient of determination is $0.7672=0.588$ thus the performance of teachers in the learning process $58,8 \%$ influenced by the culture of work, while $41.2 \%$ interest in entrepreneurship learning is influenced by other factors.
\end{abstract}

Keywords: certified teacher performanc, work culture.

\section{ABSTRAK}

Guru merupakan salah satu unsur yang sangat penting dalam sistem pendidikan dan kinerja guru merupakan hasil pencapaian dari seorang guru yang menentukan kualitas pendidikan tersebut. Guru dalam menghasilkan kinerjanya tidak akan terlepas dari budaya kerja yang diterapkan di suatu lembaga pendidikan. Maka dari itu, budaya kerja akan mempengaruhi kinerja guru.Penelitian ini memiliki tujuan untuk mengetahui adakah pengaruh antara budaya kerja terhadap kinerja guru bersertifikasi dalam PBM (proses belajar mengajar). Penelitian ini menggunakan pendekatan penelitian kuantitatif dengan jenis korelasional fungsional. Sampel yang digunakan adalah sampel jenuh atau sensus. Penelitian ini dilakukan di MA Daarul 'Uluum Lido Cigombong Bogor dengan respondennya adalah tujuh belas guru bersertifikasi. Adapun teknik pengambilan data adalah kuisioner, wawancara, observasi dan dokumentasi. Validitas data menggunakan validitas ahli dan uji validitas. 
Realibilitas data menggunakan teknik Cronbach's Alpha. Uji prasyarat analisis yang digunakani adalah uji normalitas dan uji linearitas. Untuk uji hipotesis dilakukan dengan regresi linier sederhana. Hasil akhir dari penelitian ini menunjukkan signifikansi persamaan regresi dengan hasil nilai thitung 4,631 dan tabel dengan pada taraf kesalahan $5 \% \mathrm{dk}=17-1=$ 16 adalah 1,746 pada taraf $5 \%$. Dengan demikian $t_{\text {hitung }}>t_{\text {tabel }}(4,631>1,746)$ sehingga $H_{0}$ ditolak, artinya terdapat pengaruh yang signifikan antara budaya kerja terhadap kinerja guru bersertifikasi. Koefisien determinasi yaitu $0,767^{2}=0,588$ dengan demikian kinerja guru dalam proses belajar mengajar sebesar 58,8\% dipengaruhi oleh budaya kerja, sedangkan $41,2 \%$ kinerja guru bersertifikasi dipengaruhi faktor lain.

Kata Kunci: budaya kerja, kinerja guru bersertifikasi.

Salam B, M Ma'ufur, dan S Laeli. 2017. Pengaruh budaya kerja terhadap kinerja guru bersertifikasi di Madrasah Aliyah. Tadbir Muwahhid 1(1): 32-41.

\section{PENDAHULUAN}

Sumber daya manusia dalam suatu negara adalah kunci utama yang berperan dalam memajukan negara tersebut. Dalam menghasilkan sumber daya manusia yang berkualitas diperlukan pendidikan yang berkualitas. Maka dari itu, pendidikan menjadi faktor yang sangat berperan dalam memajukan SDM di suatu negara.

Pendidikan yang berkualitas adalah pendidikan yang diselenggarakan di suatu sekolah, yang guru-gurunya mempunyai kinerja yang baik. Kinerja yang baik tersebut terlihat dari PBM yang dilaksanakan oleh guru baik di kelas atau pun di luar kelas. Guru yang baik akan melayani muridnya dengan berkualitas, dengan ini maka tujuan pendidikan akan tercapai.

Kinerja guru yang maksimal sangat diharapkan oleh semua pihak sekolah baik itu murid, kepala sekolah, wali murid dan masyarakat maupun pemerintah. Karena dengan kinerja guru yang maksimal ini mampu memberikan kontribusi yang maksimal sehingga hasil yang dicapai akan memuaskan. Ketika guru mampu melaksanakan tugasnya dengan baik dan dilakukan secara efektif dan efisien maka akan berpengaruh terhadap keberlangsungan proses belajar mengajar. Untuk menciptakan kinerja guru yang baik maka guru harus memiliki kompetensikompetensi, di antaranya adalah; kompetensi pedagogik, kompetensi kepribadian, kompetensi sosial, dan kompetensi professional (UU No. 14 Tahun 2005 tentang Guru dan Dosen). Dengan memiliki empat kompetensi ini, diharapkan guru dapat menjalankan tugasnya yaitu mendidik dan mengajar serta membimbing murid-murid secara maksimal sehingga dapat menghasilkan lulusan yang maksimal.

Madrasah Aliyah Daarul Uluum Lido Cigombong adalah salah satu sekolah yang dapat dikatakan sebagai sekolah yang berkualitas karena memiliki akreditasi A. Selain itu, MA Daarul Uluum Lido ini merupakan salah satu unit pendidikan bagian dari Pondok Pesantren Daarul Uluum Lido dengan sistem Pondok Pesantren (Boarding School) ini MA Daarul Uluum Lido ini memiliki nilai yang spesial dibanding dengan sekolah umum lainnya, yaitu adanya dua kurikulum yakni kurikulum dari Depa rtemen Agama dan kurikulum internal MA Daarul Uluum. Dalam Pondok Pesantren ini para ustadz (guru) dan santri (murid) akan mendapatkan nilai lebih yang berharga agar kelak menjadi sumber daya manusia 
(output) yang berkualitas. Dalam rangka memajukan MA Daarul 'Uluum Lido, pimpinan pondok pesantren melakukan upaya untuk menumbuhkan budaya kerja. salah satu budaya kerja ikhlas yang menjadi prioritas dalam bekerja (mengajar). Setiap guru diharuskan bekerja dengan ikhlas agar berkontribusi secara maksimal.

Sebagai komitmen dalam melaksanakan aturan-aturan yang ditetapkan di pondok pesantren Daarul Uluum Lido, pimpinan pondok pesantren senantiasa memberikan perhatian kepada para guru dengan memberikan perhatian baik berupa moral maupun material. Berupa moral dengan memberikan pengawasan terhadap guru dan material berupa pemberian kompensasi, menyediakan fasilitas ibadah, rumah, ruang guru, ruang kantor yang kondusif dan nyaman. Namun, kenyataan di lapangan masih ada guru yang tidak mematuhi aturan-aturan yang dibuat pondok pesantren. Aturan tersebut merupakan wujud penerapan budaya kerja yang berlaku di MA Daarul Uluum Lido.

Berdasarkan hasil observasi di MA Daarul 'Uluum Lido masih terdapat permasalahan yaitu terdapat beberapa guru masuk ke kelas dengan terlambat atau tidak tepat waktu, guru yang tidak disiplin dalam berpakaian. Dalam hal kinerja guru ketika PBM juga ditemukan bahwa masih terdapat beberapa guru tidak membawa RPP ke dalam kelas ketika proses belajar mengajar, masih ada guru yang mengajar bukan pada mata pelajaran yang merupakan sertifikasinya, dalam proses belajar mengajar masih terdapat guru yang belum menggunakan metode yang menarik.

\section{MATERI DAN METODE}

\section{Materi}

\section{Budaya Kerja}

Menurut Guno (2000), budaya kerja adalah falsafah yang berdasarkan pandangan hidup yang menjadi sifat, kebiasaan, dan pendorong yang dibudayakan dalam kelompok dan tercermin dalam sikap, kemudian menjadi perilaku, cita-cita, pendapat, pandangan, serta tindakan yang terwujud sebagai suatu kerja. Sementara itu, menurut Darodjat (2015), budaya kerja merupakan suatu kebiasaan dalam pekerjaan yang dibudayakan pada suatu kelompok sebagai bentuk kerja yang tercermin dari perilaku, dari waktu bekerja sehingga perilaku dan kebiasaan yang secara otomatis tertanam di dalam diri mereka masing-masing.

Budaya Kerja guru adalah nilai-nilai, kepercayaan, moral, norma, dan etika yang dilakukan oleh guru dalam melaksanakan kewajibannya sehinggga menjadi suatu kebiasaan yang melekat. Nilai-nilai, kepercayaan, moral, norma, dan etika guru tersebut dapat diketahui dari bagaimana cara pemahaman guru mengenai pekerjaannya, sikap dan perilaku pada saat bekerja.

Menurut Budi Paramita dalam Ndraha (2005), budaya kerja dibagi menjadi dua unsur, yaitu:

1. Sikap terhadap pekerjaan, yakni kesukaan terhadap bekerja daripada kegiatan yang lain seperti bersantai, atau sikap semata-mata ingin memperoleh kepuasan dari kesibukan pekerjaannya sendiri, atau juga merasa terpaksa melakukan sesuatu hanya untuk kebutuhan dan kelangsungan hidupnya.

2. Perilaku ketika bekerja, yakni rajin, berdedikasi, bertanggung jawab, 
berhati-hati, teliti, cermat, kemauan yang kuat untuk mempelajari tugas dan kewajibannya, suka membantu rekan kerja atau sebaliknya.

Foniman, Nugroho, dan Azzaini (2014) menjelaskan bahwa kerja ikhlas adalah bentuk usaha terarah untuk mendapatkan sebuah hasil yang diperoleh dari kesucian hati sebagai manifestasi kemuliaan dirinya. Guru yang bekerja dengan ikhlas akan menganggap bahwa mengajar itu adalah suatu ibadah yang didasari karena Allah Swt. Dengan ini guru akan mewujudkan kualitas kerja didasarkan karena sematamata ibadah kepada Allah Swt. sehingga akan menghasilkan kinerja yang maksimal dan optimal. Hal tersebut sesuai dengan Wahyu Allah SWT dalam Al-Quran Surat AlAn'am ayat 162 .

\section{Kinerja Guru}

Mangkunegara (2013) berpendapat bahwa kinerja merupakan hasil kerja yang secara kualitas dan kuantitas yang dihasilkan oleh seorang pegawai dalam melaksanakan tugas sesuai dengan wewenang dan tanggung jawab yang diberikan kepadanya. Sementara itu, menurut Donelly yang dikutip oleh Rivai dkk (2011), kinerja adalah tingkat keberhasilan seorang pekerja dalam melaksanakan tugasnya serta kemampuan untuk mencapai tujuan yang telah ditetapkan.

Bernawi dan Arifin (2012), kinerja adalah tingkat keberhasilan seseorang atau suatu kelompok dalam melaksanakan tugas sesuai dengan wewenang dan tanggungjawabnya berdasarkan standar kinerja yang ditetapkan selama periode tertentu sebagai rangka untuk mencapai tujuan organisasi. Kinerja guru berarti prestasi kerja guru dalam melaksanakan tugas sebagai seorang pendidik sesuai dengan wewenang dan tanggungjawabnya berdasarkan standar kinerja guru yang ditetapkan pada periode tertentu sebagai upaya dalam mencapai tujuan pendidikan.

Dalam Pedoman Pelaksanaan Penilaian Kinerja Guru (2012) dijelaskan bahwa penilaian kinerja guru dalam proses belajar mengajar dapat dilihat dari empat aspek yaitu; perencanaan pembelajaran, pelaksanaan pembelajaran, penilaian prestasi belajar, dan tindak lanjut.

Menurut Barnawi dan Arifin (2012), menjelaskan bahwa kinerja guru dapat dipengaruhi faktor internal dan eksternal. Fakor internal meliputi; 1) Kemampuan, 2) keterampilan, 3) kepribadian, 4) persepsi, 5) motivasi menjadi guru, 6) pengalaman lapangan, dan 7) latar belakang keluarga.

Sementara itu, faktor eksternal di antaranya 1) gaji; 2) sarana dan prasarana; 3) lingkungan kerja fisik; 4) kepemimpinan. Sementara itu, menurut Triguno (2000) faktor yang mempengaruhi kinerja guru (prestasi kerja guru) adalah budaya kerja.

Menurut Kunandar (2007), sertifikasi guru adalah proses seleksi yang dilakukan untuk memberikan sertifikat kepada guru yang telah memiliki dan memenuhi standar kualifikasi dan standar kompetensi guru. Berdasarkan definisi ini berarti bahwa kinerja guru bersertifikasi dalam PBM adalah hasil kerja dari seorang guru yang lulus sertifikasi dalam mata pelajaran tertentu dalam melakukan proses pembelajaran.

\section{Hipotesis}

Adapun hipotesis yang dilakukan dalam penelitian ialah sebagai berikut.

$\mathrm{H}_{0}$ tidak ada pengaruh yang signifikan antara budaya kerja terhadap kinerja guru bersertifikasi dalam proses belajar mengajar di MA Daarul Uluum Lido.

$\mathrm{H}_{1}$ ada pengaruh yang signifikan antara 
budaya kerja terhadap kinerja guru bersertifikasi dalam proses belajar mengajar di MA Daarul Uluum Lido.

\section{Metode}

\section{Tempat dan Waktu Penelitian}

Penelitian ini dilakukan di MA Daarul 'Uluum Lido Cigombong Bogor. Subjek penelitian adalah guru bersertifikasi di MA Daarul 'Uluum Lido Cigombong Bogor yang aktif pada tahun ajaran 2016/2017 berjumlah 17 guru yakni 13 laki-laki dan 4 perempuan. Waktu pelaksanaan penelitian dilakukan pada Oktober 2016 s.d. Maret 2017.

\section{Metode Penelitian}

Desain penelitian yang dilakukan dalam penelitian ini menggunakan pendekatan kuantitaif. Penelitian kuantitatif merupakan penelitian yang dipakai untuk menjawab suatu permasalahan yang diteliti melalui teknik pengukuran yang tepat dan akurat terhadap variabel-variabel tertentu, sehingga dapat mennghasilkan simpulansimpulan yang dapat digeneralisasikan. (Arifin 2012).

Jenis penelitian ini adalah korelasi fungsional yang bertujuan untuk mengetahui pengaruh variabel $\mathrm{X}$ (Budaya Kerja) terhadap variabel Y (Kinerja Guru). Adapun alat analisis penelitian ini adalah analisis regresi linier sederhana. Metode regresi digunakan untuk mengetahui dan mengungkap bagaimana antar variabel saling berhubungan. (Supardi 2012).

Dalam penelitian terdapat dua variabel yaitu variabel independen atau sering disebut dengan variabel bebas yaitu variabel yang dapat mempengaruhi atau menjadi penyebab timbulnya variabel terikat. Adapun variabel independen dalam penelitian ini adalah budaya kerja dan variabel dependen disebut juga variabel terikat yaitu variabel yang dipengaruhi atau yang menjadi akibat karena adanya variabel independen.

Populasi penelitian ini adalah seluruh guru bersertifikasi di MA Daarul 'Uluum Lido Cigombong Bogor tahun ajaran 2016/2017 berjumlah 17 guru, 13 guru lakilaki dan 4 guru perempuan. Adapun teknik sampling menggunakan teknik sampling jenuh. Menurut Sugiyono (2009), teknik sampling jenuh merupakan teknik dalam penentuan sampel jika seluruh anggota dari populasi disertakan sebagai sampel.

\section{Teknik Pengumpulan Data}

Teknik pengambilan data menggunakan kuisioner dengan skala likert untuk variabel X dan Y, serta observasi, wawancara dan dokumentasi untuk data pendukung lainnya. Uji coba instrument dilakukan melalui validitas ahli dan uji validitas serta uji reliabilitas.

\section{Teknik Analisis Data}

Setelah itu, data-data yang sudah didapat atau terkumpul kemudian diolah dan dianalisis dengan menggunakan bantuan program SPSS 16. Adapun analisis yang dilakukan ialah sebagai berikut.

1. Uji Prasayat Analisis.

Uji prasyarat analisis menggunakan uji normalitas dengan memakai Kolmogorov Smirnov dan uji linieritas.

\section{Analisis Deskriptif}

Analisis deskriptif bertujuan untuk memberikan gambaran terhadap subjek atau objek yang diteliti melalui data sampel maupun populasi tanpa melakukan analisis dan membuat simpulan yang berlaku untuk umum. (Sugiyono, 2003: 29).

3. Korelasi Product Moment 
Analisis ini dilakukan untuk mengatahui ada tidaknya hubugan antara variabel $\mathrm{X}$ dan variabel Y. Dengan dasar pengambilan keputusan jika nilai signifikansi $<0.05$ yang berarti terdapat korelasi, sebaliknya jika nilai signifikansi $>0.05$ maka tidak terdapat korelasi. (Supardi, 2012: 161).

\section{Menentukan Persaman Regresi}

Teknik analisis data dalam penelitian ini yaitu statistik inferensial, Sugiyono (2009: 184) menuturkan bahwa statistik inferensial digunakan untuk menganalisis data sampel yang kemudian hasilnya diberlakukan untuk populasi. Adapun rumus regresi linier sederhana yang dipakai adalah sebagai berikut; $\mathrm{Y}=a+b X$.

5. Uji t

Pengujian yang dilakukan untuk menguji signifikansi hubungan. jika $r$ hitung $>r$ tabel maka H1 diterima (Sugiyono, 2009: 85).

\section{Menentukan Koefisien Determinasi}

Nilai koefisien determinasi biasanya dinyatakan dalam kuadrat dari nilai koefisien korelasi $r 2 x \quad 100 \%=n \%$, bermakna bahwa nilai variabel terikat dapat dipengaruhi oleh variabel bebas sebesar $\mathrm{n} \%$, sedangkan sisanya sebesar (100-n)\% dipengaruhi oleh variabel lain. (Supardi, 2012: 180).

\section{HASIL DAN PEMBAHASAN}

\section{Hasil}

Penelitian ini dilakukan di MA Daarul 'Uluum Lido Cigombong Bogor. Subjek penelitian adalah guru bersertifikasi di MA Daarul 'Uluum Lido Cigombong Bogor yang aktif pada tahun ajaran 2016/2017 berjumlah 17 guru yakni 13 laki-laki dan 4 perempuan. Waktu pelaksanaan penelitian dilakukan pada Oktober 2016 s.d. Maret 2017.

\section{Budaya Kerja}

Hasil dari analisis statistik deskriftif data pada variabel hasil budaya kerja adalah, terdapat hasil skor tertinggi 164, skor terendah 126, rata-rata 150,29 , standar deviasi 10,48, median 151, dan modus 161 dengan melihat Tabel 1.

Tabel 1 Nilai distribusi budaya kerja

\begin{tabular}{clr}
\hline No. & \multicolumn{1}{c}{ Rentang Skor } & F \\
\hline 1 & $34-61,2$ & 0 \\
2 & $61,3-88,4$ & 0 \\
3 & $88,5-115,6$ & 0 \\
4 & $115,7-142,8$ & 2 \\
5 & $142,9-170$ & 15 \\
\hline
\end{tabular}

Hasil analisis menunjukkan budaya kerja sangat baik berada pada $88 \%$, budaya kerja baik berada pada $12 \%$, budaya kerja sedang $0 \%$, budaya kerja buruk $0 \%$ dan budaya kerja sangat buruk 0\%. Dengan demikian budaya kerja guru bersertifikasi di MA Daarul 'Uluum Lido Cigombong Bogor, sudah sangat baik karena berada pada kategori sangat baik. Hal tersebut dapat diketahui melalui diagram lingkaran pada Gambar 1.

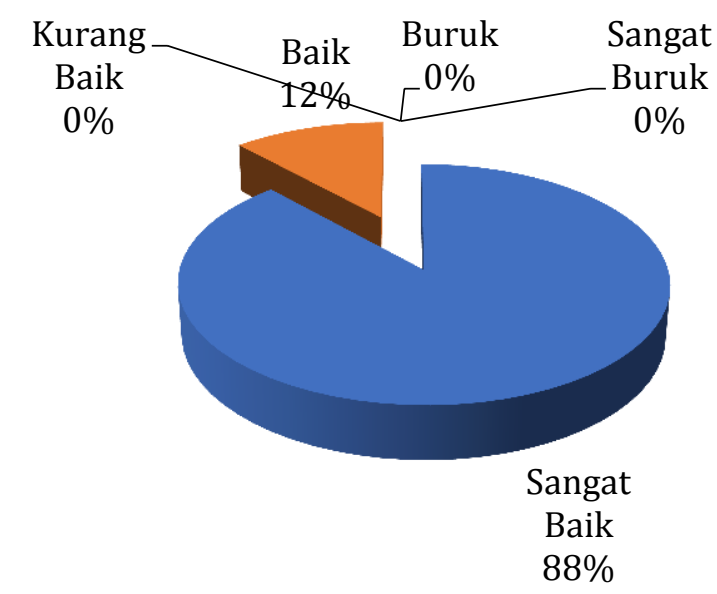

Gambar 1 Persentase budaya kerja 


\section{Kinerja Guru}

Hasil dari analisis statistik deskriftif data pada variabel kinerja guru dalam PBM adalah, terdapat hasil skor tertinggi 174 , skor terendah 120, rata-rata 153,4, standar deviasi 13,8, median 156, dan modus 157 dengan melihat Tabel 2.

Tabel 2 Nilai distribusi kinerja guru

\begin{tabular}{llr}
\hline No. & \multicolumn{1}{c}{ Rentang Skor } & \multicolumn{1}{c}{ F } \\
\hline 1 & $36-64,8$ & 0 \\
2 & $64,9-93,6$ & 0 \\
3 & $93,7-122,5$ & 0 \\
4 & $122,6-151,2$ & 6 \\
5 & $151,3-180$ & 11 \\
\hline
\end{tabular}

Hasil analisis menunjukkan kinerja guru yang sangat tinggi berada pada 81\%, kinerja yang tinggi berada pada 19\%, kinerja yang sedang $0 \%$, kinerja yang rendah $0 \%$ dan kinerja yang sangat rendah $0 \%$.

Dengan demikian kinerja guru bersertifikasi dalam PBM di MA Daarul 'Uluum Lido Cigombong Bogor, sudah sangat baik karena berada pada kategori sangat baik. Hal tersebut dapat dilihat pada diagram batang pada Gambar 2.

Uji Persyaratan analisis data menggunakan teknik uji normalitas dengan Tabel 4 Nilai distribusi kinerja guru jenis Kolmogorov Smirnov dan uji linieritas, adapun hasil nya adalah sebagai berikut.

Berdasarkan hasil Tabel 3 dapat diketahui bahwa nilai signifikansi sebesar $0,991>0,05$, sehingga berarti bahwa data yang telah diuji berdistribusi normal.

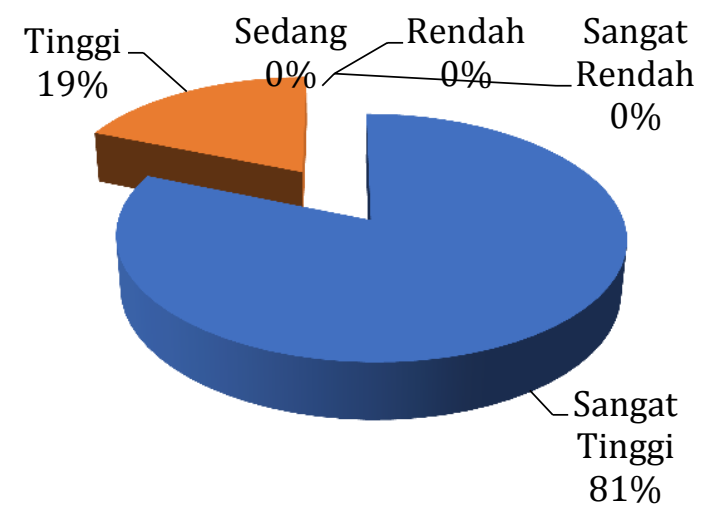

Gambar 2 Persentase kinerja guru bersertifikasi

Tabel 3 Nilai distribusi kinerja guru

\begin{tabular}{llr}
\hline & & $\begin{array}{c}\text { Unstandardized } \\
\text { Residual }\end{array}$ \\
\hline $\mathrm{N}$ & Mean & 17 \\
Normal & .0000000 \\
Parameters $^{\mathrm{a}}$ & Std. & 8.85152603 \\
& Deviation & .106 \\
Most Extreme & Absolute & .072 \\
Differences & Positive & -.106 \\
& Negative & .436 \\
Kolmogorov-Smirnov Z & .991 \\
Asymp. Sig. (2-tailed)
\end{tabular}

\begin{tabular}{llrrrrr}
\hline & Sum of Squares & Df & Mean Square & F & Sig. \\
\hline Between Groups & (Combined) & 2865.618 & 13 & 220.432 & 3.664 & .156 \\
& Linearity & 1792.525 & 1 & 1792.525 & 29.793 & .012 \\
& Deviation from & 1073.092 & 12 & 89.424 & 1.486 & .415 \\
& Linearity & 180.500 & 3 & 60.167 & & \\
Within Groups & & 3046.118 & 16 & & & \\
Total & & & & &
\end{tabular}

Berdasarkan tabel 4 diketahui nilai Sig. $0,415>0,05$, maka antara budaya kerja dan minat kinerja guru terdapat hubungan yang bersifat linier. Selanjutnya, uji linier dengan melihat $F_{\text {tabel, diketahui }} F_{\text {tabel }}$ adalah 3,68 dan $F_{\text {hitung }} 1$,486. Maka $F_{\text {hitung }}<F_{\text {tabel, yang }}$ artinya ada hubungan yang linier antara budaya kerja dan kinerja guru. 
Tabel 5 Hasil uji product moment

\begin{tabular}{|c|c|c|c|}
\hline & & xbudaya_kerja & ykinerja_guru \\
\hline \multirow[t]{5}{*}{ xbudaya_kerja } & Pearson Correlation & 1 & $.767^{* *}$ \\
\hline & Sig. (2-tailed) & & .000 \\
\hline & Sum of Squares and Cross-products & 1757.529 & 1774.941 \\
\hline & Covariance & 109.846 & 110.934 \\
\hline & $\mathrm{N}$ & 17 & 17 \\
\hline \multirow[t]{5}{*}{ ykinerja_guru } & Pearson Correlation & $.767^{* *}$ & 1 \\
\hline & Sig. (2-tailed) & .000 & \\
\hline & Sum of Squares and Cross-products & 1774.941 & 3046.118 \\
\hline & Covariance & 110.934 & 190.382 \\
\hline & $\mathrm{N}$ & 17 & 17 \\
\hline Correlat & significant & 0.01 & (2-tailed). \\
\hline
\end{tabular}

Pengujian dipakai untuk membuktikan ada atau tidak ada pengaruh antara budaya kerja dan kinerja guru bersertifikasi dalam PBM yang meliputi, korelasi product moment, persamaan regresi, uji $t$ dan mencari koefisien determinasi.

Dalam tabel 5 diketahui berdasarkan nilai signifikansi sebesar 0.000 dan nilai $F_{\text {tabel }} 0.05$, maka antara nilai signifikansi $0,000<0,05$ yang artinya terdapat korelasi antara budaya kerja terhadap kinerja guru. Berdasarkan tanda $\left(^{*}\right)$ pada program SPSS pada nilai $0,767^{* *}$ maka ada korelasi yang Tabel 6 Persamaan regresi dan uji T signifikan antara budaya kerja dengan kinerja guru bersertifikasi. Kemudian nilai keofisien 0,767 termasuk ke dalam kategori tingkat hubungan yang kuat dengan demikian dapat disimpulkan bahwa terdapat pengaruh yang kuat antara budaya kerja terhadap kinerja guru bersertifikasi dalam PBM di MA Daarul 'Uluum Lido Cigombong Bogor.

Berikutnya menentukkan persamaan regresi beserta uji $t$ (uji signifikansi hubungan). Dengan hasil yang dapat dilihat pada Tabel 6.
Unstandardized Coefficients

Model

B

1.629

1.010
Standardized

Coefficients

Beta T Sig.

Std. Error

32.848

$.050 \quad .961$

.218 $\begin{array}{lll}.767 & 4.631 & .000\end{array}$

a. Dependent Variable: ykinerja_guru

Berdasarkan pada Tabel 6 dapat diketahui bahwa besarnya konstanta 1,629 dan nilai koefisien regresi 1,010, maka persamaan regresinya adalah.

$\mathrm{Y}=a+b X$

$\mathrm{Y}=1,629+1,010 X$

Prediksi (Kinerja Guru) $=1,629+1,010$

Budaya Kerja

\section{Pembahasan}

Nilai koefisien (b) bertanda positif $(1,010)$ maka dapat dikatakan hubungan antara budaya kerja terhadap kinerja guru merupakan hubungan yang berbanding lurus. Artinya semakin tinggi budaya kerja maka semakin tinggi pula kinerja guru.

Uji t berdasarkan tabel diperoleh nilai $t_{\text {hitung }}: 4,361$ dan $t_{\text {tabel }}$ dengan $\mathrm{df}_{\text {reg }}=2-1=1$, 
$\mathrm{df}_{\text {res }}=17-1=16$ adalah 1,746 pada taraf $5 \%$. Dengan demikian $t_{\text {hitung }}>t_{\text {tabel }}(4,631>$ 1,746) sehingga $\mathrm{H}_{0}$ ditolak berarti terdapat pengaruh yang signifikan antara budaya kerja terhadap kinerja guru bersertifikasi dalam PBM di MA Daarul 'Uluum Lido Cigombong Bogor.

Tabel 7 Koefisien Determinasi

\begin{tabular}{ccccc}
\hline Model & $\mathrm{R}$ & $\mathrm{R}$ & Adjusted & Std. Error \\
Square & R Square & of the
\end{tabular}

Estimate

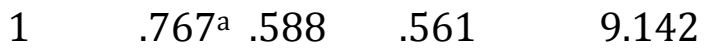

a. Predictors: (Constant), xbudaya_kerja

Berdasarkan tabel 7 diperoleh korelasi antara budaya kerja denga kinerja guru adalah 0,767 artinya terdapat hubungan yang positif dan signifikan sebesar 0,767 anata budaya kerja terhadap kinerja guru bersertifikasi dalam PBM di MA Daarul 'Uluum Lido Cigombong Bogor.

Adapun Koefisien determinasi yaitu $0,767^{2}=0,588$. Dengan demikian kinerja guru bersertifikasi dalam PBM sebesar $58,8 \%$ dipengaruhi oleh budaya kerja, sedangkan 41,2\% kinerja guru bersertifikasi dalam PBM dipengaruhi faktor lain.

\section{KESIMPULAN DAN IMPLIKASI}

\section{Kesimpulan}

Berdasarkan penelitian yang dilakukan penulis menyimpulkan bahwa Budaya kerja guru bersertifikasi di MA Daarul 'Uluum Lido Cigombong Bogor sangat baik dan memberikan pengaruh terhadap kinerja guru dalam proses pembelajaran, dan kinerja guru bersertifikasi dalam proses belajar megajar di MA Daarul 'Uluum Lido Cigombong Bogor termasuk sangat tinggi yang menunjukkan bahwa guru bersertifikasi sudah memiliki komitment dan tanggung jawab serta keikhlasan bekerja untuk selalu meningkatkan kualitas proses belajar menjagar.

Terdapat pengaruh antara budaya kerja terhadap kinerja guru bersertifikasi dalam proses belajar mengajar di MA Daarul 'Uluum Lido Cigombong Bogor 58,8\% ditentukan oleh budaya kerja guru. Selanjutnya $\quad 41,2 \% \quad$ kinerja guru bersertifikasi di MA Daarul Uluum Lido Cigombong Bogor ditentukan oleh variabel lain yang tidak diteliti dalam penelitian ini.

\section{Implikasi}

Dari hasil penelitian yang telah dilakukan dan telah disimpulkan menunjukkan bukti ilmiah bahwa terdapat pengaruh budaya kerja terhadap kinerja guru. Maka akan berimplikasi seandainya budaya kerja guru seperti kesukan terhadap bekerja, tingkat kedisiplinan, dedikasi, tanggung jawab, kemauan kuat untuk mengembangkan kemampuan diri dan murid, dan bekerja dengan ikhlas lebih ditingkatkan dan diperhatikan maka akan memberikan dampak yang positif yaitu meningkatkatnya kinerja guru dalam proses belajar mengajar yang nantinya akan mendukung tercapainya tujuan pemebelajaran. Selain itu, pimpinan pondok juga memiliki peran dalam memberikan kewajiban kepada guru-guru untuk membentuk budaya kerja yang baik, didukung dengan keadaan lingkungan yang dapat memberikan kenyamanan bagi guru untuk dapat memaksimalkan kinerjanya.

\section{DAFTAR PUSTAKA}

Arifin Z. 2012. Penelitian pendidikan: metode dan paradigma baru. Remaja Rosdakarya, Bandung.

Barnawi dan M Arifin. 2012. kinerja guru profsional instrumen pembinaan, 
peningkatan dan penilaian. Ar-Ruzz Media, Yogyakarta.

Darodjat TA. 2015. Pentingnya budaya kerja tinggi dan kuat absolute. Rineka Aditama, Bandung.

Kementerian Pendidikan \& Kebudayaan. 2012. Pedoman pelaksanaan penilaian kinerja guru: pembinaan dan pengembangan profesi guru buku 2 . Diakses dari www.slideshare.net/purdiyanto/penilaia n-kinerjaguru-pkg pada tanggal 28 Desember 2016 pukul 11.03 WIB.

Kunandar. 2007. Guru profesional: implementasi KTSP dan sukses dalam sertifikasi guru. Edisi revisi ke-7. Rajagrafindo Persada, Jakarta.

Mangkunegara AP. 2013. Manajemen sumber daya manusia perusahaan. Remaja Rosdakarya, Bandung.

Ndraha T. 2005. Teori budaya organisasi. Rineka Cipta, Jakarta.

Sugiyono. 2013. Metode Penelitian pendekatan kuantitatif, kualitatif, dan R\&D. Alfabeta, Bandung.

Supardi. 2012. Aplikasi statistika dalam penelitian. Ufuk Press, Jakarta.

Triguno. 2000. Budaya kerja (falsafah, tantangan, lingkungan yang kondusif, kualitas dan pemecahan masalah). Golden Terayon Press, Jakarta. 